\title{
Lies in a Time of Threat: Betrayal Blindness and the 2004 U.S. Presidential Election
}

\section{Eileen L. Zurbriggen*}

University of California, Santa Cruz.

Some of the most perplexing exit polls from the 2004 U.S. presidential election indicated overwhelming support for President Bush among voters who said they valued honesty, even though the Bush administration had been sharply criticized for deceiving the public, especially concerning the reasons for invading Iraq. A psychological theory recently developed to help explain memory loss in trauma survivors sheds light on this paradox. Betrayal Trauma Theory states that memory impairment is greatest when a victim is dependent on the perpetrator. The theory also predicts who will be "blind" to signs of deception - those who are emotionally or financially dependent on the person who is lying. Although every American is dependent on the U.S. President to some extent, religious conservatives may be more psychologically dependent than others. Because they believe their core values are under attack, they depend on powerful leaders such as President Bush to defend these values. This psychological dependence may make it difficult for them to notice the administration's deceptions.

Some of the most perplexing exit polls from the 2004 U. S. presidential election indicated overwhelming support for President Bush among voters who said they valued honesty. Writing in the New York Times, Scott Purdum reported that "Voters who cited honesty as the most important quality in a candidate broke 2 to 1 in Mr. Bush's favor, despite Mr. Kerry's relentless accusations that Mr. Bush had misled the public into war." (Purdum, 2004). This irony was not lost on The Nation's Katrina vanden Heuvel, who tartly queried "The most mendacious Administration in American history won the honesty vote?" (vanden Heuvel, 2004). Indeed, the

\footnotetext{
* Correspondence concerning this article should be addressed to Eileen L. Zurbriggen, Department of Psychology, Room 277, Social Sciences 2, University of California, Santa Cruz, Santa Cruz, CA 95064 [e-mail: zurbrigg@ucsc.edu].

Portions of this article were written while the author was a Visiting Research Associate at Smith College.
} 
disconnect between voters' professed values and the record of their preferred candidate demands explanation. A psychological theory recently developed to explain memory loss in trauma survivors helps shed light on this paradox.

\section{Betrayal Trauma Theory and Betrayal Blindness}

Psychologists have long known that many (but not all) trauma survivors have gaps in their memory (Janet, 1889; Kardiner, 1941; Myers, 1916, 1940; Rivers, 1918). Some have no conscious knowledge of the traumatic event at all (Elliott $\&$ Briere, 1995). Memory impairment has been documented among a variety of populations including survivors of child sexual abuse and combat veterans (for a review, see Brown, Scheflin, \& Hammond, 1998).

Although suggestion can also play a role in memory for trauma (Schooler, 1999), forgetting, amnesia, or dissociation are present in many survivors and are likely to be functional and adaptive in some way. Several clinicians and researchers have argued that it is especially painful traumas that are more likely to be forgotten or repressed (e.g., Freud, 1913; Goleman, 1985; Green, 1992; Greenson, 1967). Recently, however, Freyd (1994, 1996, 2002) has argued that dependence and betrayal are more important factors in dissociation and memory loss than is fear. Her Betrayal Trauma Theory (BTT; Freyd, 1996) explains why this would be so.

Consider the case of a young child, dependent for survival on an adult caregiver. Like all humans, this child has strong (perhaps hard-wired) psychological mechanisms that help detect betrayal. Cosmides and Tooby (1992) dubbed these mechanisms "cheater detection procedures" because they help in recognizing someone who is trying to gain an advantage. When the cheater detection procedures fire, the normal response is anger and rejection of the cheater. It is adaptive and self-protective to choose to have no further dealings with someone who lies and does not play by the rules.

This strategy works well in most cases, but it fails when one is dependent on the betrayer for physical or emotional survival. This is typically the case for young children being abused by a caregiver. Responding to betrayal in the normal way - by getting angry and leaving the field — could result, quite literally, in death. BTT argues that a rational and adaptive solution to this dilemma is to deny that the perpetrator's actions are abusive or, even better, to not notice the perpetrator's actions (e.g., through the mechanism of dissociation). If the child's cheater detectors do not fire, they will not lead him or her to do anything that might increase the risk for abandonment by the caregiver.

A similar analysis can apply in adult relationships. For example, when infidelity occurs in a marriage, the wronged spouse often is blind to clues that, to an outsider, seem impossible to miss. BTT predicts that this "betrayal blindness" is more likely to occur when the wronged spouse is especially dependent on his or her partner, either financially or emotionally. In those cases, one is better off not noticing the lies. 
BTT predicts that unawareness, dissociation, and forgetting will be most common when the victim is dependent on the perpetrator, and this prediction has been supported empirically in a number of studies. In a reanalysis of several prospective (Williams, 1994; 1995) and retrospective (Cameron, 1993; FeldmanSummers \& Pope, 1994) data sets, Freyd (1994) found consistent evidence that survivors of incestuous abuse (i.e., abuse by a family member) had more memory impairment than did survivors of nonincestuous abuse. Stoler (2001) also found more delayed memories among women who were more closely related to their abusers. Although classifying perpetrators according to family relationship is an imperfect proxy for dependency (e.g., an uncle may visit infrequently and not affect one's day-to-day life; a camp counselor or priest may have an emotionally close relationship with children under his or her care), there is nevertheless a strong correlation between family relationship and dependency. Thus, it is a reasonable proxy variable. In addition, subsequent studies have asked specifically about closeness with perpetrators (Schultz, Passmore, \& Yoder, 2003) or about whether the perpetrator was a caregiver (Freyd, DePrince, \& Zurbriggen, 2001). These studies found more memory impairment for abuse that was perpetrated by caregivers or others who were emotionally close to the victims, supporting the predictions of BTT.

\section{Betrayal Blindness and the 2004 Presidential Election}

Betrayal Trauma Theory may also have relevance for the 2004 U.S. presidential election. In an era in which the United States is the sole global superpower, every citizen of this country (and, indeed, every living creature on the planet) is affected by the policies and actions of the U.S. president and is therefore dependent on him, at least to some extent. But some people are likely to be more psychologically dependent than others. Many conservative voters, especially fundamentalist Christians, are convinced that their core values, those most central to their moral and personal identity, are under attack by "godless" liberals. As individuals, they feel helpless to counteract this attack. They are forced to depend on powerful others, most especially leaders like President Bush, to do so for them. According to BTT, once this psychological dependence occurs, betrayal blindness is likely to follow. It would then become more difficult for these voters to notice the administration's deceptions and fabrications at the time they are being uttered, or to remember them clearly at a later date.

Perceived emotional closeness may be an important factor in this political scenario, as it is in the prototypical interpersonal scenario of childhood abuse by a caregiver. For the abused child, the dissociation, the needing to "not know," derives directly from the need to maintain the attachment bond. Although few Americans have a personal relationship with President Bush, many of his supporters feel connected to him. Poll results indicated that voters found President Bush more easygoing and likeable than Senator Kerry; he is the one they 
would prefer to "have a beer with" (Schlesinger \& Calmes, 2004). This affiliative connection, even though it is imagined rather than realized in actual personal contact, probably increases the likelihood of betrayal blindness. If conservative voters noticed the administration's lies, demanded an accounting from the president, and were then abandoned or punished by him, not only would their most important values and beliefs be in danger, their imagined friendship and closeness with the President would disappear as well. Better not to notice that anything is amiss - that way the connection and protection will both continue unthreatened.

In contrast, people who oppose President Bush tend to have strong feelings of antipathy towards him, not just as a political actor, but as a person (Brownstein, 2004). Fear of losing an attachment bond with the president is not an issue for this group of people. They do not like the president, do not want to be close to him, and do not feel emotionally dependent on him. This lack of desire for an attachment bond would likely mitigate betrayal blindness that could arise from practical dependence on President Bush's actions and policies (which these voters share with all Americans). Similarly, any Bush supporters who dislike him as a person (but are voting for him because they agree with his policies) should be less susceptible to betrayal blindness than supporters who like and feel close to him.

Although the focus of BTT is on the relationship between the abuser and the victim, Freyd has proposed that other factors may also be important in predicting amnesia (Freyd, 1996, p. 140). A few of these factors (e.g., young age at time of abuse, isolation during abuse) are not immediately relevant. However, others seem to have a parallel in the political situation under analysis. For example, Freyd argued that explicit threats demanding silence will lead to impaired memory. In the case of sexual abuse, the child is not allowed to talk about the abuse with other people; total secrecy is demanded. The similarities to the current administration are striking. In response to a comment by late-night talk show host Bill Maher (who said that the September 11 hijackers were not cowards), White House press secretary Ari Fleischer announced that "people have to watch what they say and watch what they do" (Carter \& Barringer, 2001). More generally, the Bush administration has been described as one of the most secretive in modern memory (Samuels, 2004). A Congressional minority staff report on this topic concluded that the Bush administration's actions have led to "an extraordinary expansion of government secrecy" resulting in "an unprecedented assault on the principle of open government" (United States House of Representatives Committee on Government Reform - Minority Staff, 2004). President Bush has also been accused of being especially intolerant of criticism (Wilgoren, 2004). His demand for loyalty from his staff was satirized by political cartoonist Garry Trudeau, who wrote several series of strips featuring a new Bush Cabinet member-the "Secretary of Toady Affairs" (Trudeau, 2005). 
Another factor that Freyd (1996, p. 140) predicts will lead to betrayal blindness is "alternative reality-defining statements by [the] caregiver." Often these statements have an Orwellian quality to them, in that they completely reverse the truth. Perpetrators will tell a child that the abuse is an expression of love, and the child enjoys and wants everything that is happening. Although most successful politicians are adept at "spinning" the truth, the Bush administration has been particularly egregious in its use of Orwellian phrases (e.g., the "Healthy Forests Initiative" to describe a plan to cut down more trees, the "Clear Skies Initiative" to describe a plan that will ultimately allow more pollutants in the air); The Washington Post opined that "more often than not, you can assume that the measure will accomplish almost precisely the opposite of what its name boasts" "Return," 2005). The Bush administration also has come under fire for its attempts to manipulate public opinion by producing prepackaged video "news" segments sympathetic to its policies (Barstow \& Stein, 2005) and for paying journalists and pundits to provide favorable commentaries (Kornblut, 2005). In an in-depth account of the dynamics of the Bush White House, Suskind (2004) provided a quote from an unnamed Bush aide that quite explicitly articulated the administration's desire to control the definition of reality. The aide dismissed Suskind as being part of "the reality-based community," comprising people who "believe that solutions emerge from your judicious study of discernible reality." The aide continued, "That's not the way the world works anymore. We're an empire now, and when we act, we create our own reality. And while you're studying that reality-judiciously, as you will —we'll act again, creating other new realities, which you can study too, and that's how things will sort out. We're history's actors ... and you, all of you, will be left to just study what we do." (Suskind, 2004, p. 51).

\section{Caveats and Implications}

Other perspectives besides BTT can, of course, help to explain the findings under consideration here. For example, classic theories of cognitive consistency offer a variety of mechanisms (e.g., ignoring or reinterpreting evidence, paying less attention to contradictory messages, modifying an attitude) that can be used to reduce the dissonance that arises when two or more beliefs (e.g., "I value honesty," "I plan to vote for Mr. Bush," "The Bush administration just told a lie") are in conflict. Other research has shown that in times of political or economic threat, levels of authoritarianism rise (Doty, Peterson, \& Winter, 1991). Given that submission to legitimate authorities is a key component of authoritarianism, it seems plausible that people high in this trait would believe and trust authority figures such as the president. Thus, a rise in authoritarianism might lead to increasing difficulty in perceiving lies by authority figures. These alternative perspectives are not necessarily in conflict with betrayal trauma theory. They might operate in parallel with the dependency-based forgetting predicted by BTT, or they may describe 
some of the mediating mechanisms that result in dependency-based forgetting. In any event, a full profile of factors related to political beliefs and voting behavior (even just within the context of the 2004 presidential election) would, of course, be expected to show individual differences related to many variables, not just dependence.

Furthermore, nothing in the present analysis is meant to imply that there are differences in basic psychological processes across political group or ideology. A fundamentalist Christian from Kansas is no more or less susceptible to betrayal blindness than is a liberal feminist Manhattanite. According to BTT, both individuals will be unlikely to notice and remember the lies of a politician on whom they feel dependent. However, these two individuals are unlikely to feel highly dependent on the same politicians. I have argued that the fundamentalist Christian might well feel both practically and emotionally dependent on President Bush. In contrast, the liberal feminist is unlikely to feel strong dependence on President Bush. However, she might have felt high levels of dependence on President Clinton, especially if she believed that abortion rights were under attack and that Clinton alone had the power to protect those rights. According to BTT, such feelings of dependence would likely have led to some amount of betrayal blindness concerning Clinton's lies about his affair with Monica Lewinsky (and, in fact, feminists were criticized for being too willing to accept Clinton's initial denials [Cooper, 1998], suggesting that betrayal blindness might have been in operation).

The present analysis has some discouraging implications. It suggests that the more dangerous the world becomes, the less we may be able to distinguish truth from lies. If the situation in Iraq continues to worsen, feelings of insecurity and the need for protection are likely to increase. Assuming the Bush administration continues its deceptive practices, one should not expect conservative Americans to suddenly notice that they are being lied to. Because of the increasing feelings of threat and insecurity, betrayal blindness will likely be even stronger than it is now. Ironically, because the American soldiers and civilians in Iraq are especially dependent on the U.S. government for physical protection (e.g., in supplying suitably armored vehicles), they may accept administration deceptions as easily as does the rest of the country, in spite of the fact that many of them have personal access to evidence contradicting statements made by the administration.

On the other hand, BTT offers some encouragement, in that it suggests a way to break the link between perception of threat and blindness to deceptions by authorities. According to BTT, if dependence on those authorities can somehow be reduced, the ability to separate lies from truth should spring back to life. Political activists have long argued that resistance and social change are most effective when they are collective (rather than individualistic) projects. One reason for this effectiveness may be that taking collective action breaks the feeling of dependence on politicians and the government, leading to many positive outcomes, including an enhanced ability to judge the veracity of governmental pronouncements. 


\section{References}

Barstow, D., \& Stein, R. (2005, March 13). Under Bush, a new age of prepackaged news. The New York Times, pp. A1, A34-A35.

Brown, D. P., Scheflin, A. W., \& Hammond, D. C. (1998). Memory, trauma treatment, and the law. New York: Norton.

Brownstein, R. (2004, October 31). Why 'This is about Bush'. Los Angeles Times, pp. A1-A28.

Cameron, C. (1993, April). Recovering memories of childhood sexual abuse: A longitudinal report. Paper presented at the meeting of the Western Psychological Association, Phoenix, AZ.

Carter, B., \& Barringer, F. (2001, September 28). In patriotic time, dissent is muted. New York Times, pp. A1, B8.

Cooper, G. (1998, February 1). Clinton's crisis: Why America's feminists are strangely muted. The Independent [London], p. 22. Retrieved June 13, 2005 from LexisNexis database.

Cosmides, L., \& Tooby, J. (1992). Cognitive adaptations for social exchange. In J. H. Barkow, L. Cosmides, \& J. Tooby (Eds.), The adapted mind: Evolutionary psychology and the generation of culture (pp. 163-228). New York: Oxford University Press.

Doty, R. M., Peterson, B. E., \& Winter, D. G. (1991). Threat and authoritarianism in the United States, 1978-1987. Journal of Personality and Social Psychology, 61, 629-640.

Elliott, D. M., \& Briere, J. (1995). Posttraumatic stress associated with delayed recall of sexual abuse: A general population study. Journal of Traumatic Stress, 8, 629-647.

Feldman-Summers, S., \& Pope, K. S. (1994). The experience of "forgetting" childhood abuse: A national survey of psychologists. Journal of Consulting and Clinical Psychology, 62, 636-639.

Freud, S. (1913). In J. Riviera (Trans.), The interpretation of dreams (3rd ed.). London: Allen and Unwin.

Freyd, J. J. (1994). Betrayal-trauma: Traumatic amnesia as an adaptive response to childhood abuse. Ethics and Behaviour, 4, 307-329.

Freyd, J. J. (1996). Betrayal trauma: The logic of forgetting childhood abuse. Cambridge, MA: Harvard University Press.

Freyd, J. J. (2002). Memory and dimensions of trauma: Terror may be "all-too-well remembered" and betrayal buried. In J. R. Conte (Ed.), Critical issues in child sexual abuse: Historical, legal, and psychological perspectives (pp. 139-173). Thousand Oaks, CA: Sage.

Freyd, J. J., DePrince, A. P., \& Zurbriggen, E. L. (2001). Self-reported memory for abuse depends upon victim-perpetrator relationship. Journal of Trauma and Dissociation, 2(3), 5-17.

Goleman, D. (1985). Vital lies, simple truths: The psychology of self-deception. New York: Simon and Schuster.

Green, L. (1992). Ordinary wonders: Living recovery from sexual abuse. Toronto, ON: Women's Press

Greenson, R. R. (1967). The technique and practice of psychoanalysis. (Vol. 1). New York: International Universities Press.

Janet, P. (1889). L'automatisme psychologique. Paris: Félix Alcan.

Kardiner, A. (1941). The traumatic neuroses of war. New York: Paul Hoeber.

Kornblut, A. E. (2005, January 29). Third journalist was paid to promote Bush policies. New York Times, p. A17.

Myers, C. S. (1916). Contributions to the study of shell shock: Being an account of certain cases treated by hypnosis. Lancet, 187, 65-69.

Myers, C. S. (1940). Shell shock in France 1914-18. Cambridge: Cambridge University Press.

Purdum, T. S. (2004, November 3). All about the President: After a disputed election four years ago, Bush seems poised to claim a new mandate. New York Times, pp. A1, P10.

Return of the $\$ 1$ million donor. (2005, June 24). The Washington Post, p. A30.

Rivers, W. H. R. (1918). An address on the repression of war experience. Lancet, 191, 173-177.

Samuels, D. (2004, November 1). Psst. President Bush is hard at work expanding government secrecy. New York Times, p. A24

Schlesinger, J. M., \& Calmes, J. (2004, October 8). In Bush vs. Kerry, Part II, style matters. Wall Street Journal, p. A4.

Schooler, J. W. (1999). Seeking the core: The issues and evidence surrounding recovered accounts of sexual trauma. In L. M. Williams \& V. L. Banyard (Eds.), Trauma and memory (pp. 203-216). Thousand Oaks, CA: Sage. 
Schultz, T., Passmore, J. L., \& Yoder, C. Y. (2003). Emotional closeness with perpetrators and amnesia for child sexual abuse. Journal of Child Sexual Abuse, 12, 67-88.

Stoler, L. R. (2001). Recovered and continuous memories of childhood sexual abuse: A quantitative and qualitative analysis. Doctoral dissertation, University of Rhode Island, 2001. Dissertation Abstracts International, 61(10-B), 5582.

Suskind, R. (2004, October 17). Without a doubt. New York Times Magazine, pp. 44-51, 64, 102, 106. Trudeau, G. B. (2005, March 14). New secretary of toady affairs settles in. The Washington Post, p. C3.

United States House of Representatives Committee on Government Reform - Minority Staff. (2004, September 14). Secrecy in the Bush administration. Retrieved June 13, 2005 from http://www.fas.org/sgp/library/waxman.pdf

vanden Heuvel, K. (2004, November 3). Stand and fight. The Nation. [Weblog: Editor's Cut]. Retrieved June 13, 2005 from http://www.thenation.com/blogs/edcut?bid=7\&pid=1979

Wilgoren, J. (2004, March 28). Kerry accuses Bush camp of intolerance for criticism. New York Times, p. A28.

Williams, L. M. (1994). Recall of childhood trauma: A prospective study of women's memories of child sexual abuse. Journal of Consulting and Clinical Psychology, 62, 1167-1176.

Williams, L. M. (1995). Recovered memories of abuse in women with documented child sexual victimization histories. Journal of Traumatic Stress, 8, 649-674.

EILEEN L. ZURBRIGGEN is an associate professor of psychology at the University of California, Santa Cruz. The overarching goal of her research program is to understand how sexual thoughts, feelings, and behaviors are culturally constructed and to explore the social and intrapsychic consequences of those constructed sexualities. She is especially interested in the eroticization of dominance and submission because of the many pressing social problems (e.g., rape, sexual harassment, child sexual abuse, domestic violence) that arise, in part, from this particular construction of sex. 